\title{
Church as Hostile, Host or Home: Perspectives on the Experiences of African Migrants in South Africa
}

\section{Buhle Mpofu}

\begin{abstract}
Human migration has been on the rise globally and it has fuelled xenophobia and growing intolerance towards migrants in the receiving communities. This article draws from data collected for a $\mathrm{PhD}$ thesis and highlights the experiences of African migrants in religious spaces and congregations in Johannesburg, South Africa. The $\mathrm{PhD}$ project this article draws from identified Christian religious identities as a form of belonging and explored models for providing care to migrants and refugees by appreciating their agency and ensuring that cross cultural and socio-religious encounters enrich the developmental agenda within host communities. I argue that instead of being hostile to African migrants, host congregations and communities should engage in mutually transformative mission with migrants and appreciate how migration encounters enrich human relations. They give birth to hybrid contextual theologies through the construction, or de-construction, of congregations by missio-ecclesiological and intercultural forces of migration that challenge their vocation and witness.
\end{abstract}

Keywords: Migration, Hostility, Host, Theology, Mission, Ecclesiology

\section{Introduction}

It is a generally held view that models of providing care and support to migrants have to focus on integration, assimilation, or cohesion. The work of 


\section{Buhle Mpofu}

Jonathan Sacks provides helpful insights into these concepts in his book The Home We Build Together (2009). Sacks, as a political advisor, policy maker and leader of the Jewish Community in the United Kingdom, developed three parables as a framework for understanding the relationship between the integration and assimilation of newcomers in local communities. In these parables he tells the fate of one hundred strangers who have been wondering around the countryside in search of a dwelling place and eventually find themselves at the gate of, first, a large guesthouse, secondly a hotel and, thirdly, are welcomed as residents. Sacks contrasts the implications for living in the hotel, the guesthouse and being a resident of the City emphasizing that cooperation between the City dwellers and the newcomers is key to development. Rather than keeping newcomers in guesthouses or expensive hotels, the city has town planners, engineers, builders, and experts who can design and build homes for the new citizens. They set out to work together and unlike in the guesthouse or hotel, the newcomers have an opportunity to invest their energy and build their own houses. In this, local residents have an active role to play as they work with their newly found residents. Based on this model, this article draws on these parables to highlight the differences between Church as hostile, host, and home for migrants within the new congregations of the Uniting Presbyterian Church in Southern Africa (UPCSA) in Johannesburg, South Africa. In so doing, I use the term church to denote a local community of Christian believers who regularly gather for worship, and/ or a congregation.

In a presentation at the global consultation for theological students at World Council of Churches (WCC) Assembly in Nov 2013, I identified the global experiences of migrants and refugees as an emerging ecumenical challenge for the $21^{\text {st }}$ century and warned that churches should prepare for a coordinated response in the wake of growing intolerance and xenophobic attacks (Mpofu 2013). This article highlights the experiences of African migrants within churches in Johannesburg and draws on the themes which emerged in my $\mathrm{PhD}^{1}$ study; church as hostile, host or home with the aim to

${ }^{1}$ The Thesis was entitled, 'When the people move, the Church moves': A Critical Exploration of the Interface between Migration and Theology through a Missional Study of Selected Congregations within the Uniting Presbyterian Church of Southern Africa in Johannesburg. This study demonstrated how migrants appropriate their vulnerability and marginalization to reinvent and 
contribute towards alternative models of care which value the agency of migrants. The article also advocates for academic engagement that places emphasis on the experience of migration as the centre for transformational theological reflection.

\section{Literature Review}

Given the increased multi-directional movement of people in search of better living conditions globally, there is growing competition for space and resources between host communities and migrants or refugees. Data collected through my $\mathrm{PhD}$ thesis highlighted the experiences of African migrants within the religious spaces of the congregations in Johannesburg and identified Christian religious identity as a form of belonging in contested spaces. In cities like Johannesburg, where there are many African migrants, space is increaseingly becoming important in observing and understanding contemporary forms of belonging and their social organization (Conradson \& Latham 2005; Nathan 2011; Caglar \& Schiller 2011). The nation-state has ceased to be the locus of cultural intersections, and instead a more complex space of diasporic contacts structured by globalized trends is emerging in cities (Sassen 1991).

Religion plays an important role in the development and formation of identities in modern cities, and its role in shaping the identity of people on the move through their lived experiences of migration has been ignored by many scholars in the discipline of religion and migration. Hagan and Ebaugh (2003:39) have noted that:

Despite the diversity and prominence of religious beliefs and practices among contemporary immigrants ..., scholars of both immigration and religion have tended to neglect the role of religion and spirituality in the process of international migration.

Generally, the role of religion in various stages of the migration process, including in decision-making about routes and settlement, have been overlooked by social scientists and policymakers alike (Hagan \& Ebaugh 2003). Riem Spielhaus (cited in Suarez-Orozco 2008:70) a scholar of Islam,

recreate metaphors of survival through constructing or deconstructing new forms of identity in contested transnational religious spaces. 


\section{Buhle Mpofu}

explains that ' $[\mathrm{n}] \mathrm{ew}$ comers bring with them ideas, customs, and traditions that may be unfamiliar to their host communities'. One of the most visible symbols of these traditions includes houses of worship where migrants gather to retain their sense of identity and pass on their culture to the next generation. In the light of this symbolic significance of the construction of houses of worship, Spielhaus argues that building mosques in Europe has become controversial because houses of worship have powerful symbolic value. Religious identity is therefore one of the means through which migrants affirm their presence and retain contact with their cultural values from the homelands. Reflecting on the struggles experienced by Filipino domestic workers in Hong Kong, Cruz (2010:6) echoes similar sentiments about the religious experiences of migrants:

Religious discourse and religious means provide the domestic workers the much-needed courage, hope, and faith in the struggle .... Religious groups and/or fellowships are established as instruments for forming ties ... and to help them deal with and/ or resist the ambiguities, discontinuities, and difficulties, that arise ....

Hospitality with regards to the role of the churches in providing care for migrants has drawn scholarly attention in the field of religion/ theology, with the focus on migration developing from two distinct perspectives. According to Settler (2018) the field can be delineated into two fields with the first being concerned with how migrants move with, and use their religious traditions and practices. He suggests this is especially characteristic in theologies of migration insofar as they focus on discourses of incorporation and hospitality. For Settler the second approach is a more sociological inquiry into how migrants use and access churches, mosques, and other religious sites for building social networks and to harness resources for resilience.

Interrogating the complexities around the church's reception of migrants is a significant contribution to the missional church conversation and presents a paradigm shift for reflections about what it means to be a community called church. Within the changing situations of our contemporary times, it also offers an alternative hermeneutic for reading and interpreting the Bible in the light of the experience of migration. Another profound contributor to missiological thinking in Southern Africa, David Bosch, through his seminal work, Transforming Mission: Paradigm Shifts in Theology of Mission (1991) highlighted the historical and theological dimensions of different paradigms in 
mission from the early church through to what he refers to as 'the emerging ecumenical paradigm'. Bosch believed that the $21^{\text {st }}$ century would see developments that could push the church to seek a new paradigm - the 'emerging ecumenical paradigm'. He cites the factors behind the emergence of this new paradigm such as Western governments losing dominance in global governance, challenging of unjust structures of oppression and exploitation, how western technology and the developmental agenda are now treated with suspicion and how European theologies can no longer claim universal superiority given that freedom of religion is considered a human right. Indeed, the presence of migrants and refugees at our borders and communities present challenges to our context and if embraced as an opportunity, we can engage in enriching and transformative encounters for both new comers and host communities. But developing programs for such enriching experiences will require alternative theological and missional development that draws on the interface between theology, migration, development, and religio-cultural diversity as means to achieve social cohesion, peace, and stability.

\section{Research Methodology}

The empirical data I draw on in this article was collected during my $\mathrm{PhD}$ research with respondents drawn from three formerly white congregations of the Uniting Presbyterian Church in Southern Africa (UPCSA). The congregations Yeoville, Mayfair and Turfontein are all situated within the larger Johannesburg area. This research included fieldwork over a period of three months and data was collected through focus group discussions, interviews with key informants, as well as self-administered questionnaires. The names and positions of participants (29 in total, i.e. 13 women and 16 men) were anonymised to protect the identity of the participants and the questions were designed to gather information about age, length of stay in Johannesburg, economic status, living conditions, their experiences and perceptions about living in Johannesburg and participation in UPCSA congregations.

\section{Analysis of Empirical Data}

The analysis of extracts from the focus group participants and statements from interviews identified the lived experiences of African migrants within the church according to two themes; firstly, issues relating to the church's 
engagement with migrants, and secondly, those related to the church's attempts to incorporate migrants. Themes in the first category highlighted the hostility directed towards African migrants from the church and the wider society, for example shame and vulnerability, while the themes in the second category pointed to the impediments of the church's mission towards incorporation of migrants and focused on the attempts to salvage the missionary vision of the church as the 'Family and Kingdom of God', a home for all people called by God. In particular, this article isolates data that highlights the differences between how migrants view the church as hostile, host, or home.

\section{Church as Hostile}

The theme of 'church as hostile' emerged from the data in which respondents articulated negative statements about how they felt received and treated by members of the local congregations. This hostility of the church towards migrants was also reflected in sub-themes; compassion fatigue [members of congregations seemingly tired of showing compassion to migrants], migrants' struggle for recognition and human dignity, and experiences of shame and vulnerability. All of these were characterised by a 'us and them' mentality where relations between South Africans and African migrants were persistently uneasy and often xenophobic.

They were there just telling us 'you people we don't want you' (Don, $27^{\text {th }}$ April 2015).

This statement is very hostile and instils a sense of fear and insecurity among migrants. The words were expressed by a Home Affairs Official to a migrant as he went to register his marriage.

While running an errand for her hair salon in which she employs three South Africans, Ruth was confronted by a local South African who got into a heated argument about business opportunities for local South Africans. When she explained that she was in South Africa to do business, she was asked why she did not do her business back in the Democratic Republic of Congo.

If things are fine in your country what are you doing here (Ruth, 27 ${ }^{\text {th }}$ August 2015). 
These statements confirmed findings from other studies that some South Africans have negative attitudes towards foreigners and accuse them of crime, stealing their jobs and taking their women (Crush, Ramachandran \& Pendleton 2013). The hostility directed towards migrants in Johannesburg exposes them to vulnerability as they are constantly under threat of violence, and they feel ashamed as they lack recognition as human beings with a dignity. Given repeated incidences of hostility and growing anger towards foreigners that we often witness in South African communities with foreign migrants, there is an urgent need for alternative responses to the challenge of migration, not just in South Africa but globally.

In the following statement, Abdul expressed disappointment with the current generation of Africans and their failure to live together in harmony and address contemporary challenges collectively as the historical fathers did during the struggle against colonialism in Africa.

Historical fathers like Mandela like Nkurumah, like Nyerere, like Patrice Lubumba, were able to stand together even to liberate their countries because of the spirit of Ubuntu, they saw themselves as African (Abdul, 30 ${ }^{\text {th }}$ August 2015).

It is a call to unity in the face of divisions and when Abdul speaks of the 'spirit of Ubuntu', he draws from the concept of African communal life that is based on an African worldview that places emphasis on 'umuntu ngumuntu ngabantu' (lit: 'a person is a person because of other people'). This is a worldview that views people not as individuals, but individuals only in relation to the community and the world of nature around them. This concept derives from the readiness to share and care for one another. Yet, compassion fatigue has led to hostile encounters between migrants and locals, as locals feel too burdened to care for African migrants. We are witnessing a similar form of fatigue in Europe where migrants fleeing wars in Syria and North Africa are stranded at the borders to Europe. A similar fatigue has been noted by Orobator (2005:167) during his field work in East Africa:

Refugees are rejected by host communities for whom their presence portends disaster for their already strained economic and ecological resources .... This situation has severely compromised the muchvaunted African spirit of solidarity, generosity and hospitality ... 
[and] Today supportive evidence of 'African hospitality' for refugees has become harder to find.

\section{Church as Host}

Another interesting theme that emerged from this study was the incorporation of migrants through what I call the (in)visible church. By (in)visible church I refer to the blurred understanding of who or what constitutes the church as reflected by the respondents' inconsistent use of terms such as they, these, and those to refer to local congregations. As a result, they spoke of the church in ways where it was not clear who or what constitutes church. Is the church an institution, the buildings, or the people who inhabit it? If it is the people, does that include everyone including migrants?

If they can have space and use that space to talk to the government .... because they know very well that these people are foreigners (Kevin, $30^{\text {th }}$ August 2015).

In some instances, migrants spoke about the church as if they were not a part of it, using words such as 'these people', 'they' to distinguish between local church members from themselves. Statements such as 'the church should have the means to support its members' (Ruth, 30 ${ }^{\text {th }}$ August 2015), indicate that the migrants who participated in the study viewed the church as an institution that exists 'out there', without them. However, in reality the migrants are a part of the church and their agency in transforming the communities in which they live should be recognised. These mixed perceptions of the identity and role of the church impact on the missio-ecclesial responses of the church to the lived experiences of African migrants.

As indicated above, there were tensions between what the migrant participants perceived as Christian practice (missional) and church identity (ecclesial) in the face of the realities regarding their experiences. Even more interesting, by associating themselves on the basis of country of origin migrants selectively engaged in discriminating against each other on the basis of their country of origin, but did not seem to view such associations as discriminatory. As the migrants struggle to maintain ties with people from their own countries and cultural backgrounds, they simultaneously attempt to integrate into new communities as they seek to build the ideal family of God. 
At the core of migrants' understanding of church is a vocation that revolves around a welcoming and hospitable faith community with life affirming relationships. Where this does not exist the institutional church is viewed as a far removed and irrelevant system, what I argue is the (in)visible church.

The following statement made by a South African is a clear defence of the church, confirming the perception that migrants are a 'burden to the church'.

I'm not trying to be racist or what, to be honest, the church has a lot of duties and we can't keep putting more duties for the church (Steve, $26^{\text {th }}$ April 2015).

Sentiments along these lines were also echoed by other South Africans during the focus group discussions, hence raising questions about what the participants understood to be the role or identity of the church in the context of migrations. Participants alluded to this incompetency and lack of ecumenical engagement on issues affecting migrants, and compared it with how the church was a unified force in the past. For example when a local member says, 'the church has a lot of duties', this demonstrates a lack of commitment and competency in speaking out against injustices that migrants face.

\section{Church as Home}

Christian experience where we are able to share together the common love that Christ died for all of us and that love binds us all together as human beings, and because he died for us and rose again for us that brought us together as brothers and sisters and we belong to the family of God $\left(30^{\text {th }}\right.$ August 2015).

Although most respondents held strong views about the family of God living together as a 'family of God', it was clear that in practice this reality still remained a challenge. This was evidenced by the tensions that characterised the atmosphere during the focus group discussions. Participants demonstrated a strong sense of awareness that they are the people of God in exile, although 
they continued to express a conception that did not include themselves as integral parts of the church. For example, they made statements such as 'God was with the Israelites and Moses in Egypt' (30 ${ }^{\text {th }}$ August 2015). Such statements are in line with what Orobator (2005:172) has argued in relation to East African refugee communities 'they hold tenaciously to the view that uprootment, displacement, and exile do not dispossess them of the presence and protection of God' and for him 'to characterise the church in such terms has implications for our understanding of the function, meaning and theology of the church'.

The following statement implies that migrants 'feel comfortable' when they come into the presence of fellow believers (God's family) where 'there is room' for them.

They will always call on each other, and say come! there is room for us here. People feel comfortable when they have been accepted ... they feel that they are part of the congregation (27 $7^{\text {th }}$ April 2015).

However, contrary to this understanding of the church, other sentiments demonstrate that migrants do not view themselves as full members of the local church. The church is (in)visible as it is not clear who belongs to local congregations because local South Africans are not comfortable worshipping with people from other nations, hence they slowly drift out of the communities that are receiving foreign migrants and change places of worship. This is demonstrated in the views expressed by one of the local leaders below:

Even black South Africans who used to come every sun we have noticed that some of them they are not as regular and that might be speaking to change of worship styles or the kind of influence the Cameroonians have on how we should be worshipping (27 ${ }^{\text {th }}$ April 2015).

The fact that migrants speak of the church as an institution and do not see themselves as a church, reflects confusion in their understating of the ecclesial community called church. They expect to be hosted, and do not see themselves as hosts. Locals who are viewed as hosts by the foreign migrants are themselves not ready to play that role. Consequently, it is not clear who or what constitutes the church. This is contrary to the teaching that migrants belong to 
the universal family of God, and should find a home among other Christians. Being a regional and transnational community of believers gives the UPCSA a unique missional identity, and presents an opportunity for each community of faith within each nation to offer hospitality to each other. Through the church, all forms of boundaries are crossed as humanity view itself in the image of God (Imago Dei) and they can come together across borders to share the word of God (Verbum Dei) as they take part in the mission of God (Missio Dei). This understanding of the church is consistent with its mission and ecclesial identity as it draws people together towards the vision of the 'Kingdom of God' where they feel welcomed and treated with love and dignity as one of the leaders pointed out during the interviews.

\section{Discussion}

Given the hostility and growing intolerance directed toward migrants, the presence of migrants and refugees in our communities constitutes a challenge to Christian mission and points to the need for development of new models of 'neighbourhood' built on dialogue and hospitality. It is in this regard that notable efforts to understand the role of spirituality in the lives of refugees and migrants from the African perspective need to be commended. Orobator (2005:164) raised a question; '[w]hat is the Church on a continent where 20 million people live in exile?' Orobator (2005) confirmed that refugees have a widely held view of the church which portrays 'refugeeness' as a test of faith. The church should be concerned with the presence of unwelcome strangers in any community in which it engages in mission because the Judeo-Christian faith is informed by scriptural perspectives of treating strangers with hospitality. Therefore, any authentic Christian theological reflection should address all forms of ethnic and national divisions and promote diversity. Stephen Bevans (2008:89) views the church 'as a community with and of migrants' and suggests that the community that is called church must be located within the wider context of God's action and plan for humanity. This implies that the church is a community of pilgrims; people who are on a 'God directed journey' and as such, a community that understands and identifies with the migrants and refugees in the face of hostility and threats to life.

Hostility towards African migrants can be addressed through improved visibility of the church, and the integration of migrants into local congregations and communities. According to Kapuscinski (2005), 


\section{Buhle Mpofu}

remains of market places, of ports, of places where there were agoras and sanctuaries, of where the seats of old universities and academies are still visible, and of where there remain vestiges of such trade routes as the Silk road, the Amber Route and the Trans-Saharan caravan route, give evidence of different human encounters scattered across the planet as proof of successful cooperation during crosscultural encounters ... the 'other' stopped being a synonym of foreignness and hostility.

The significant observation that Kapuscinski makes is that people had three choices when encountered with the 'Other': (1) they could choose war; (2) they could build a wall around themselves, or alternatively, (3) they could enter into an enriching dialogue with one another. As I have already pointed out, not all South Africans are hostile towards African migrants, my research indicated that some locals were tolerant and positively engaged migrants in dialogue. Participants in this study underscored the need for the church to get involved in addressing the challenge of migration located outside of the church, citing the fact that migration is not just a challenge for the church but also for the communities.

The survival strategies of refugees observed by Orobator (2005) in East Africa are reminiscent of the reality among migrants in Johannesburg. There are migrants who have persevered in the faith in the midst of trials and tribulations, there are those who have abandoned the faith, and there some who have discovered God as their only help and comfort in exile. These revelations challenge us to think differently about the identity and mission of the church through an informed understanding of these challenges and their implications. For example, if the World Communion of Reformed Churches understands mission as the crossing of all borders that separate people from God, from one another, and from creation, it is only by crossing borders that reconciliation through Christ becomes a reality (WCRC 2010). This definition of mission takes people moving across borders seriously and according to this document, ' $\mathrm{t}$ ] he missional church is transformational and exists for the transformation of the community that it serves, through the power of the Gospel and the Holy Spirit' (WCRC 2010:164).

The findings of this study also indicate that there are contradictions between what the church teaches and what members of the church practice. This has deep theological and missional implications for the church as it points 
to inconsistency and incompetency. The presence of migrants exposes the missional weaknesses of the selected congregations and in particular, their understanding of the church and the role of the local church in the context of migration. The fact that many South Africans tend to move out of the communities and congregations that African migrants move into, is weakening the response of the local church in addressing the needs of migrants. In this regard, the model developed by Sacks (2009) may be helpful in the face of the multiple challenges presented by contemporary human mobility.

The newcomers [will] still occasionally seem strange. They [will] speak and act and dress differently than the locals. But those long sessions of working together have had their effect. The locals [will] know [that] the newcomers are serious, committed, dedicated. They have their own ways, but they have also learned the ways of the people of the town, and they have worked out ... a friendship .... Making something together breaks down walls of suspicion and misunderstanding ... that is society as the home we build together (Sacks 2009:123)

The fact that the South African law recognizes that migrants with permanent residence can own property should be a clear reminder that some migrants will remain in the country more or less permanently. In their search for recognition and human dignity in the highly competitive environment of Johannesburg, their experiences reflect the missio-ecclesial implications of the experience of migration in urban spaces. Dealing with these contemporary challenges of migration will require an alternative vision 'from below', where the voice of migrants forms the basis for missional praxis through which South Africans should not view themselves as hosts, but rather embrace African migrants as partners who can equally contribute to the development of the church and society.

\section{Concluding Remarks}

This article drew on the themes which emerged out of my PhD study- church as hostile, host or home- to highlight the experiences of African migrants in Johannesburg. I employed a model developed by Jonathan Sacks (2009) to advocate engagement which places emphasis on the experience of migration 
as the centre for transformational theological reflection. As such I have argued that there is a need for South African communities and local churches in Johannesburg to avoid hostility towards migrants and desist from regarding themselves as hosts and rather, engage migrants as mutual partners. In so doing, I contend that such transformation will require appreciating the agency and contributions of migrants in the development of South African communities as well as deeper examination of how these encounters can enrich theological, ecclesial and missional reflections.

\section{Funding acknowledgement}

The research project this article draws from was funded by NRF Thuthuka (Religion and Migration in Postcolonial South Africa) and the Council for World Mission.

\section{References}

Adogame, A. \& J. Spickard (eds.). 2010. Religion Crossing Boundaries: Transnational Religious and Social Dynamics in Africa and the New African Diaspora. Leiden: Brill.

https://doi.org/10.1163/ej.9789004187306.i-280

Bevans, S. 2008. Mission among Migrants, Mission of Migrants: Mission of the Church in a Promised Land, A Perilous Journey. In Groody, D.G. \& G. Campese (eds.): Theological Perspectives on Migration. Notre Dame: University of Notre Dame Press.

Bosch, D.J. 1991. Transforming Mission: Paradigm Shifts in Theology of Mission. Maryknoll, N.Y.: Orbis Books.

https://www.amazon.com/Transforming-Mission-Paradigm-TheologyMissiology/dp/1570759480

Çaglar, A. \& N. Glick-Schiller (eds.). 2011. Locating Migration: Rescaling Cities and Migrants. Ithaca: Cornell University Press.

Conradson, D. \& A. Latham 2005. Transnational Urbanism: Attending to Everyday Practices and Mobilities. Journal of Ethnic and Migration Studies 31,2: 227 - 233.

https://doi.org/10.1080/1369183042000339891

Crush, J., S. Ramachandran \& W. Pendleton 2013. Soft Targets: Xenophobia, Public Violence and Changing Attitudes to Migrants in South Africa after May 2008. Cape Town: The Southern African Migration Project (SAMP). 
Cruz, G. T. 2010. An Intercultural Theology of Migration: Pilgrims in the Wilderness. Leiden: The Netherlands.

https://www.amazon.com/Intercultural-Theology-Migration-Studies-

Systematic/dp/9004181229

Hagan, J. \& H.R. Ebaugh 2003. Calling upon the Sacred: Migrants' Use of

Religion in the Migration Process. International Migration Review 37, 4: 1145 - 1162.

https://doi.org/10.1111/j.1747-7379.2003.tb00173.x

Huwelmeier, G. \& K.K. Krause (eds.). 2010. Traveling Spirits: Migrants, Markets, Mobilities. New York \& London: Routledge.

Kapuscinski, R. 2005. Encountering the Other: The Challenge for the $21^{\text {st }}$

Century. New Perspectives Quarterly 22:6 - 13.

https://doi.org/10.1111/j.1540-5842.2005.00759.x

Levitt, P. 2007. God Needs no Passport: New York: The New Press.

Mpofu, B. 2012. Unwelcome Strangers: The Suffering of Migrants and

Refugees as an Ecumenical Global Challenge for the $21^{\text {st }}$ Century. Paper presentation, World Council of Churches Global Ecumenical Theological Institute. Seoul, Korea.

Mpofu, B. 2013. The Suffering of Migrants and Refugees as an Ecumenical Global Challenge for the $21^{\text {st }}$ Century. Paper Presentation, Global Ecumenical Theological Education (GETI) Program, World Council of Churches, Busan, South Korea. Oct. 25 - Nov. 9.

Mpofu, B. 2015. When the People Move, the Church Moves: A Critical Exploration of the Interface between Migration and Theology through a Missiological Study of Selected Congregations within the Uniting Presbyterian Church of Southern Africa in Johannesburg. PhD Thesis, University of KwaZulu-Natal S.A.

Nathan, M. 2011. The Economics of Super-diversity: Findings from British Cities, 2001-2006. SERC Discussion Paper 68.

Orobator, A. 2005. From Crisis to Kairos: The Mission of the Church in the Time of HIV/ AIDS, Refugees and Poverty. Nairobi: Pauline.

Sacks, J. 2009. The Home we Build Together: Recreating Society. London: Bloomsbury Academic Publishers.

Settler, F.G. 2018. A Postcolonial Perspective of Religion and Migration. In Machado, D., B. Turner \& T. Wyller (eds.): Borderland Religion: Ambiguous Practices of Difference, Hope and Beyond. Abingdon: Routledge. https://doi.org/10.4324/9781351056946-8 


\section{Buhle Mpofu}

Suarez-Orozco, C. 2008. Stories of Identity: Religion, Migration, and Belonging in a Changing World. Brookline, MA: Facing History and Ourselves. https://www.amazon.com/Stories-Identity-Religion-MigrationBelonging/dp/0979844037

World Communion of Reformed Churches 2010. Proceedings of the Uniting General Council of the World Communion of Reformed Churches. Grand Rapids, Michigan.

$$
\begin{array}{r}
\text { Buhle Mpofu } \\
\text { Post-Doctoral Fellow }
\end{array}
$$

School of Religion, Philosophy and Classics University of Kwa-Zulu Natal, South Africa buhlem202@yahoo.co.uk 